\title{
Heavy metals in municipal sewage sludge - a brief characteristic of potential threats and methods used to assess the ecological risk
}

\author{
Malwina Tytla*, Kamila Widziewicz-Rzońca \\ Institute of Environmental Engineering Polish Academy of Sciences; Poland
}

Received: 8 February 2021

Accepted: 15 March 2021

Published online: 30 May 2021

\begin{abstract}
Population growth and increasing effectiveness of biological wastewater treatment processes are reasons for a systematic increase in the amount of municipal sewage sludge. Beyond the soil forming values and fertilizer properties, sludge is highly enriched with heavy metals, including these particularly toxic to the environment $(\mathrm{Cd}, \mathrm{Cr}, \mathrm{Cu}, \mathrm{Ni}, \mathrm{Pb}, \mathrm{Zn}$, $\mathrm{Hg}$ ), which contributes to an increase in the level of ecological risk. A variety of methods (indices) have been proposed in order to assess the ecological risk of heavy metals in sewage sludge. Among them we can distinguish the total content and speciation indices. It is important to remember that total concentration of heavy metals in sewage sludge does not provide complete information about the level of ecological risk that these elements pose to the environment and living organisms, including humans. Metals bound to the sludge structure may undergo transformation while being subjected to the processes conducted in the wastewater treatment plants (WWTPs). Therefore, it is necessary to determine also their chemical forms. The common method used to identify the chemical fractions of metals in sludge, is the three - step sequential extraction by the Community Bureau of Reference procedure (BCR; now Standards, Measurements and Testing Programme).
\end{abstract}

Keywords: sewage sludge, heavy metals, ecological risk analysis, sequential extraction, threats

\section{Introduction}

The presence of heavy metals in municipal sewage sludge, by-product of wastewater treatment, apart from microbiological contamination and pollution with toxic organic compounds, is the most important criterion for its agricultural use (Duan et al. 2017; Tytła 2019). In European Union (EU) countries, the permissible concentration of heavy metals in sewage sludge is regulated by the Council Directive of 12 June 1986 (86/278/EEC). The characteristics of sludge depend mainly on the chemical composition of raw wastewater and undergo changes in the subsequent stages of sludge processing, such as: thickening, stabilization, drainage and hygienization (Wang et al. 2006; Tytła 2020). Unfortunately, chemical, physical or biological processes do not guarantee definite heavy metal removal, which may lead to the secondary contamination of the natural environment with these

\footnotetext{
* Corresponding author: Malwina Tytła

e-mail: malwina.tytla@ipispan.edu.pl
} 
elements, as well as pose a threat to living organisms, including humans (Camargo et al. 2016; Tytła 2020). Moreover, knowledge of the total content of heavy metals allows only to assess the degree of sludge contamination, but it is not equal with the possibility of releasing of these elements into the soil and ground water. The factor determining the mobility, bioavailability and toxicity of heavy metals is their chemical form (Gusiatin et al. 2018; Tytła 2019). One of the most popular methods for determination of the chemical forms of heavy metals, is the three-step sequential extraction according to BCR procedure (Community Bureau of Reference; now Standards, Measurements and Testig Programme) (Ure et al. 1993). This method allows to determine which components of sewage sludge are associated with the individual element, and also for a more accurate assessment of the ability of their migration from the sludge to the natural environment (Gusiatin et al. 2018; Chen 2019).

Analysis of the ecological risk seems to be the most proper tool for assessing the level of potential risk posed by heavy metals present in sewage sludge. This is due to the fact that ecological risk analysis relates both to the total content of heavy metals in sewage sludge, as well as to their chemical forms. We can distinguish two types of risk indices: the total content and speciation indices (Zhao et al. 2012; Tytła 2020). Some of them consider the accumulation level of heavy metals in sewage sludge, without toxicity impact, or focuses on both the total quantity of heavy metals and toxicity, while others focus on heavy metal mobility, etc. In recent years, these indices have been successfully used to assess the ecological risk in soil and sediment (Liu et al. 2015). Unfortunately, the overwhelming majority of current scientific studies concerns only the dewatered sewage sludge, without taking into account its previous characteristics and their impact on the level of final ecological risk.

\section{Description of the subject}

The main objective of this study was to provide the general information about the heavy metals in municipal sewage sludge, their sources, concentrations, chemical forms, as well as treats (risks) associated with their presence in sludge, and methods used to assess the ecological risk posed by these elements. This paper also contains a short overview of methods used to remove heavy metals from sewage sludge, as well as literature analysis by using Web of Science (WoS) database.

\section{Literature review}

\section{Heavy metals in sewage sludge}

Heavy metals are mainly found in sewage sludge due to their hydrophobic nature. These elements are associated with the solid portion of wastewater (Tiruneh et al. 2014). In EU countries, the concentration limit values of heavy metals $(\mathrm{Cd}, \mathrm{Cr}, \mathrm{Cu}, \mathrm{Ni}, \mathrm{Pb}, \mathrm{Zn}$ and $\mathrm{Hg}$ ) in sewage sludge are specified in the Council Directive of 12 June 1986 (86/278/EEC). Moreover, from 30\% to 50\% of sewage sludge is used in agriculture, which constitutes an alternative to landfill disposal or incineration (Tytła 2019). Application of sewage sludge to land solves the problem of its final disposal, but may also pose a potential ecological risk associated with the secondary contamination of soil, as well as surface and ground waters by heavy metals (Tytła 2020). There are several sources of heavy metals in sewage sludge. The most common are (Tiruneh et al. 2014; Tytła 2019; Chen 2019):

- domestic and industrial wastewaters,

- surface runoff from urbanized areas or roads,

- wastewater from the agro-industrial sector,

- corrosion of sewerage systems,

- pharmaceuticals, body care and cleaning products,

- illegal wastewater discharges.

Many scientists analyzed heavy metals contents in dewatered sewage sludge from different WWTPs. It can be observed that in municipal WWTPs, the concentration of heavy metals such as Zn 
Tytła and Widziewicz - Rzońca

and $\mathrm{Cu}$ in sewage sludge are generally high, while $\mathrm{Cd}$ or $\mathrm{Hg}$ are relatively low (Chen 2019; Tytła et al. 2019). Moreover, the content of heavy metals in sewage sludge differs depending on time and season, while the magnitude of these changes is relatively large. In Tab. 1 we presented the mean concentrations of heavy metals in sewage sludge from various municipal WWTPs.

Tab. 1. The mean concentrations of heavy metals in sewage sludge from municipal WWTPs.

\begin{tabular}{|c|c|c|c|c|c|c|c|c|c|}
\hline \multirow{2}{*}{ Location } & $\mathbf{C d}$ & $\mathbf{C r}$ & $\mathbf{C u}$ & $\mathbf{~ N i}$ & $\mathbf{P b}$ & $\mathbf{Z n}$ & $\mathbf{H g}$ & \multirow{2}{*}{ References } \\
\cline { 2 - 8 } & \multicolumn{7}{|c|}{$\mathrm{mg}^{-1}$} & & $\begin{array}{c}\text { Wang et al. } \\
\text { (2006) }\end{array}$ \\
\hline $\begin{array}{c}\text { China } \\
\text { (Gaobeidian) }\end{array}$ & - & 91.0 & 59.6 & 69.8 & 40.2 & 746.5 & - & Spanos et al. (2014) \\
\hline Greece (Kavala) & 1.6 & 52.5 & 127.8 & 21.2 & 63.7 & 1001.2 & $<0.2$ & $\begin{array}{c}\text { Gusiatin et al. } \\
(2018)\end{array}$ \\
\hline $\begin{array}{c}\text { Poland } \\
\text { (Warmia and } \\
\text { Mazury) }\end{array}$ & 1.6 & - & 216.9 & 91.5 & 8.0 & 994.5 & - & $\begin{array}{c}\text { Tytła } \\
(2019)\end{array}$ \\
\hline $\begin{array}{c}\text { Poland } \\
\text { (Bytom) }\end{array}$ & 4.1 & 67.1 & 194.0 & 95.2 & 187.8 & 1851.6 & 1.0 & \\
\hline
\end{tabular}

While analyzing the total content of heavy metals in sewage sludge, scientists also analyzed the concentration of these elements in different chemical forms (fractions). The most commonly used method to determine the chemical forms of heavy metals in sewage sludge, is the three-step chemical sequential extraction procedure of the Community Bureau of Reference (BCR; now the Standards, Measurements and Testing Programme (Ure et al. 1993). This method allows to determine the constituents of the sludge to which particular heavy metals are bound to. Moreover, it also enables a detailed assessment of the migration ability of heavy metals from sewage sludge to soil, surface and ground waters, as well as to plants (Chen 2019; Tytła 2019). BCR sequential extraction divides the sludge into four fractions, i.e. acid dissolved/exchangeable (F1), reducible (F2), oxidizable (F3) and residual (F4). Generally, sewage sludge from municipal WWTPs exhibit higher concentrations of heavy metals bound to the oxidizable and residual fractions (F3 and F4), compared to the mobile ones (F1 and F2). However, it was observed that $\mathrm{Zn}, \mathrm{Ni}$ and $\mathrm{Cd}$ may also occur in the large quantities in the easily exchangeable and reducible fractions (F1 and F2) (Gusiatin et al. 2018; Tytta et al. 2019). The scheme of the BCR sequential extraction procedure is shown in Fig. 1.

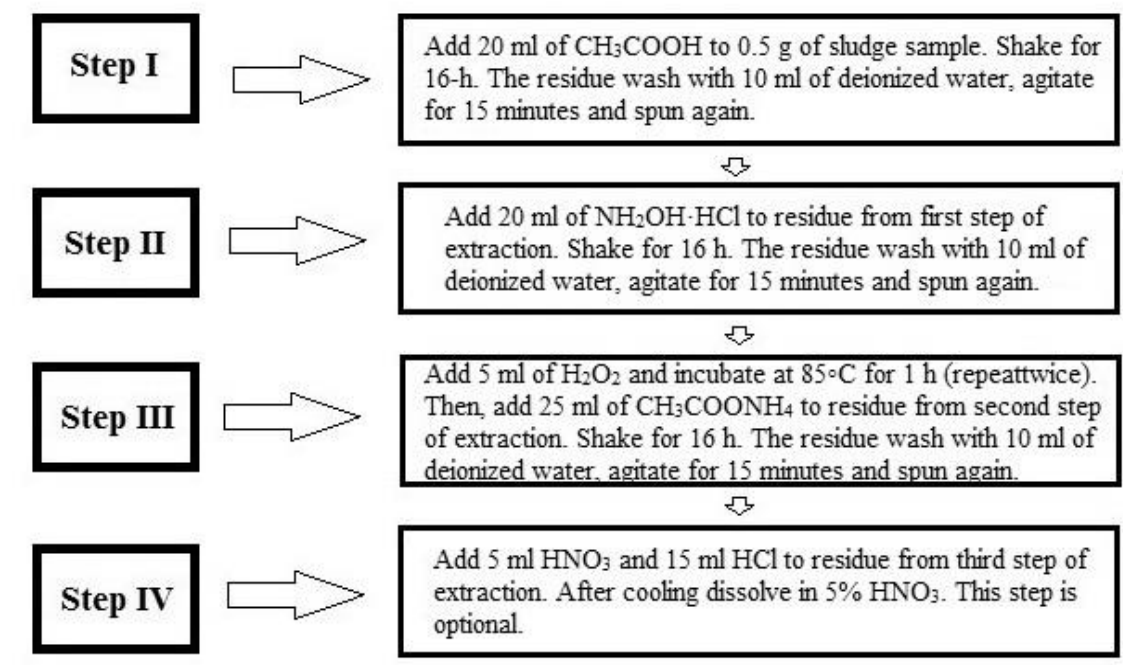

Fig. 1. Scheme of the BCR sequential extraction procedure. 


\section{Threats related to the presence of heavy metals in sewage sludge}

From many years, the world is facing with a problem of sewage sludge disposal, which touches a set of complex issues including health, environment and economics. The presence of heavy metals in sewage sludge is a crucial factor limiting its application as a fertilizer (Camargo et al. 2016; Chen 2019). Among many of the threats (risks) associated with the presence of heavy metals in sewage sludge, the most important are (Tiruneh et al. 2014; Spanos et al. 2014; Chen 2019):

- soil contamination - resulting from long-term use of sludge as a fertilizer,

- surface and groundwater contamination - resulting from leaching heavy metals from soil,

- reduction of plant yields - resulting from heavy metals accumulation in plants,

- health problems to animals and humans - resulting from the consumption of plants,

- inhibition or disruption of biological processes carried out in the wastewater treatment plants resulting from presence of heavy metals in domestic and industrial wastewaters discharge into the municipal WWTPs.

Taking into account threats associated with the presence of heavy metals in sewage sludge, as well as the lack of legal acts regulating the permissible share of a given element in mobile fractions, there is a necessity to conduct a comprehensive ecological risk analysis.

\section{Most common techniques of heavy metals removal}

Processes commonly used in municipal WWTPs do not guarantee definite removal of heavy metals from sewage sludge, but there are some techniques which may reduce their concentrations (Camargo et al. 2016; Tytla et al. 2019). Among them, we can distinguish chemical, physical and biological techniques. The first group includes the following treatments methods: acidification, alkalization and ion exchange. These methods are characterized with a high efficiency and simplicity, as well as with a short contact time required between the reagent and sewage sludge. The second group includes: heat treatment and electroremediation (electrokinetic and electrodialysis). First one requires a short exposure time, and allows high removal of selected heavy metals from sewage sludge, while electroremediation methods are characterized with a short exposure time and allow to recovering elements from the substrate. The last group of techniques includes: vermicomposting, application of biosurfactant and bioleaching. Vermicomposting has a high potential for removing heavy metals from sewage sludge without altering the nutrient composition of the substrate negatively. This method is not expensive, but needs a long exposure time. The second method seems to be promising, but it is still unknown what types of biosurfactants are more efficient for each type of substrate and element, and what conditions are the best for the proper functioning of this process. The last technique in this group is bioleaching. This is a simple, efficient and economically attractive method, which do not compromise the sewage sludge properties (like conditioning or fertilization). In conclusion, chemical and physical techniques are usually very expensive and may lead to secondary pollution of natural environment with heavy metals, whereas biological methods are less harmful to the environment, but also more time consuming, and haven't been conducted in full scale (Camargo et al. 2016). Therefore, the choice of the best method for heavy metals removal is dictated by characteristics of the sewage sludge.

\section{Methods used to assess the ecological risk of heavy metals in sewage sludge}

A variety of methods (indices) have been proposed in order to assess the ecological risk of heavy metals in sewage sludge. We can distinguish the total content and speciation indices (Zhao et al. 2012; Tytła 2020). Both types of indices are calculated in different ways and include various aspects. Many researchers used different indices to assess the ecological risk of heavy metals in sewage sludge (Duan et al. 2017; Gusiatin et al. 2018; Tytła et. al. 2020). A detailed list of methods used to assess the ecological risk of heavy metals in sewage sludge is presented in Tab. 2. 
Tytła and Widziewicz - Rzońca

Tab. 2. Methods (indices) used to assess the ecological risk of heavy metals in sewage sludge.

\begin{tabular}{|c|c|c|c|}
\hline $\begin{array}{l}\text { Geoaccumulatio } \\
\text { n Index (Igeo) } \\
\text { (Müller 1969) }\end{array}$ & $\begin{array}{l}\quad \mathbf{I}_{\text {geo }}=\log _{2}(\mathbf{C n} / \mathbf{1 . 5 B n}) \\
\text { Cn-measured concentration } \\
\text { of element in the sediment } \\
\text { sample, Bn - geochemical } \\
\text { background value in the } \\
\text { Earth's crust (Kabata-Pendias } \\
\text { 2011); }\end{array}$ & $\begin{array}{l}\mathrm{I}_{\text {geo }} \leq 0 \\
0<\mathrm{I}_{\text {geo }} \leq 1 \\
1<\mathrm{I}_{\text {geo }} \leq 2 \\
2<\mathrm{I}_{\text {geo }} \leq 3 \\
3<\mathrm{I}_{\text {geo }} \leq 4 \\
4<\mathrm{I}_{\text {geo }} \leq 5 \\
5<\mathrm{I}_{\text {geo }}\end{array}$ & $\begin{array}{l}\text { Practically uncontaminated } \\
\text { Uncontaminated to moderately } \\
\text { contaminated } \\
\text { Moderately contaminated } \\
\text { Moderately to Heavily } \\
\text { contaminated } \\
\text { Heavily contaminated } \\
\text { Heavily to Extremely } \\
\text { contaminated } \\
\text { Extremely contaminated }\end{array}$ \\
\hline $\begin{array}{l}\text { Enrichment } \\
\text { Factor (EF) } \\
\text { (Sakan et al. 2009) }\end{array}$ & $\begin{array}{l}\text { EF }=(\mathbf{C x} / \text { Cref) sample / } \\
(\mathbf{C x} / \mathbf{C r e f}) \text { background } \\
\text { Cx and Cref }- \text { concentrations } \\
\text { of the element } \mathrm{x} \text { and the } \\
\text { reference element in the } \\
\text { Earth's crust (Kabata-Pendias } \\
\text { 2011); }\end{array}$ & $\begin{array}{l}\text { EF }<1 \\
\text { EF } 1-3 \\
\text { EF 3-5 } \\
\text { EF 5-10 } \\
\text { EF 10-25 } \\
\text { EF 25-50 } \\
\text { EF }>50\end{array}$ & $\begin{array}{l}\text { No enrichment } \\
\text { Minor enrichment } \\
\text { Moderate enrichment } \\
\text { Moderately severe enrichment } \\
\text { Severe enrichment } \\
\text { Very severe enrichment } \\
\text { Extremely severe enrichment }\end{array}$ \\
\hline $\begin{array}{l}\text { Potential } \\
\text { Ecological Risk } \\
\text { Factor (ER) } \\
\text { (Hakanson 1980) }\end{array}$ & $\begin{array}{l}\qquad \mathbf{E R}=\mathbf{T} \cdot \mathbf{C F} \\
\mathrm{T}-\text { toxic response factor of } \\
\text { element; } \\
\mathrm{CF}-\text { Contamination Factor }\end{array}$ & $\begin{array}{l}\mathrm{ER}<40 \\
40<\mathrm{ER} \leq 80 \\
80<\mathrm{ER} \leq 160 \\
160<\mathrm{ER} \leq 320 \\
\mathrm{ER}>320\end{array}$ & $\begin{array}{l}\text { Low risk } \\
\text { Moderate risk } \\
\text { Considerable risk } \\
\text { High risk } \\
\text { Very high risk }\end{array}$ \\
\hline $\begin{array}{l}\text { Risk Index (RI) } \\
\text { (Hakanson 1980) }\end{array}$ & $\mathbf{R I}=\sum \mathbf{E R}$ & $\begin{array}{l}\mathrm{RI} \leq 150 \\
150<\mathrm{RI} \leq 300 \\
300<\mathrm{RI} \leq 600 \\
\mathrm{RI}>600\end{array}$ & $\begin{array}{l}\text { Low risk } \\
\text { Moderate risk } \\
\text { Considerable risk } \\
\text { High risk }\end{array}$ \\
\hline $\begin{array}{l}\text { Probable Effect } \\
\text { Concentration } \\
\text { (PEC) Threshold } \\
\text { Effect } \\
\text { Concentration } \\
\text { (TEC) (Mcdonald } \\
\text { et al. 2000) }\end{array}$ & - & $\begin{array}{l}\text { Metal }<\text { TEC } \\
\text { PEC }>\text { Metal }<\text { TEC } \\
\text { Metal }>\text { PEC }\end{array}$ & $\begin{array}{l}\text { Non-polluted } \\
\text { Neither polluted nor non-polluted } \\
\text { Polluted }\end{array}$ \\
\hline $\begin{array}{l}\text { Individual } \\
\text { Contamination } \\
\text { Factor (ICF) } \\
\text { (Ikem I in. 2003; } \\
\text { Zhao et al. 2012) }\end{array}$ & $\begin{array}{l}\qquad \mathbf{I C F}=(\mathbf{F 1}+\mathbf{F} 2+\mathbf{F 3}) / \mathbf{F} 4 \\
\text { F1-F4 }- \text { chemical fractions of } \\
\text { metals }\end{array}$ & $\begin{array}{l}\mathrm{ICF} \leq 1 \\
1<\mathrm{ICF} \leq 3 \\
3<\mathrm{ICF} \leq 6 \\
\mathrm{ICF}>6\end{array}$ & $\begin{array}{l}\text { Low contamination } \\
\text { Moderate contamination } \\
\text { Considerable contamination } \\
\text { Very high contamination }\end{array}$ \\
\hline $\begin{array}{l}\text { Risk Assessment } \\
\text { Code (RAC) } \\
\text { (Perin et al. 1985) }\end{array}$ & $\begin{array}{c}\text { RAC }=\mathbf{F} 1 \\
\text { F1 the most mobile fraction }\end{array}$ & $\begin{array}{l}\text { RAC } \leq 1 \% \\
1 \%<\text { RAC } \leq 10 \% \\
10 \%<\text { RAC } \leq 30 \% \\
30 \%<\text { RAC } \leq 50 \% \\
\text { RAC }>50 \%\end{array}$ & $\begin{array}{l}\text { No risk } \\
\text { Low risk } \\
\text { Medium risk } \\
\text { High risk } \\
\text { Very high risk } \\
\end{array}$ \\
\hline $\begin{array}{l}\text { Global Risk } \\
\text { Index (GRI) } \\
\text { (Zhao et al. 2012) }\end{array}$ & $\begin{array}{l}\text { GRI }=\sum \mathbf{T} \cdot \mathbf{I C F} \\
\mathrm{T}-\text { toxic response factor of } \\
\text { element }\end{array}$ & $\begin{array}{l}\text { GRI } \leq 150 \\
150<\mathrm{GRI} \leq 300 \\
300<\mathrm{GRI} \leq 600 \\
\mathrm{GRI}>600\end{array}$ & $\begin{array}{l}\text { Low risk } \\
\text { Moderate risk } \\
\text { Considerable } \\
\text { High risk }\end{array}$ \\
\hline $\begin{array}{l}\text { Individual } \\
\text { Ecological Risk } \\
\text { (IER) } \\
\text { (Tytła 2020) }\end{array}$ & $\begin{array}{l}\text { IER }=(\mathbf{F} 1+\mathbf{F} 2) /(\mathbf{F 3}+\mathbf{F} 4) \cdot \mathbf{1 0 0} \\
\mathrm{F} 1, \mathrm{~F} 2, \mathrm{~F} 3, \mathrm{~F} 4-\text { the content of } \\
\text { metal in each of chemical } \\
\text { fraction }\end{array}$ & $\begin{array}{l}\text { IER } \leq 50 \% \\
50 \%<\text { IER } \leq 100 \% \\
100 \%<\text { IER } \leq 250 \% \\
\text { IER }>250 \%\end{array}$ & $\begin{array}{l}\text { Low risk } \\
\text { Moderate risk } \\
\text { High risk } \\
\text { Very high risk }\end{array}$ \\
\hline $\begin{array}{l}\text { Global } \\
\text { Ecological Risk } \\
\text { (GER) (Tytła } \\
\text { 2020) }\end{array}$ & $\begin{array}{c}\text { GER }=\sum \text { IER } \\
\text { IER }- \text { Individual Ecological } \\
\text { Risk }\end{array}$ & $\begin{array}{l}\text { GER } \leq 100 \% \\
100 \%<\text { GER } \leq 250 \% \\
250 \%<\text { GER } \leq 500 \% \\
\text { GER }>500 \%\end{array}$ & $\begin{array}{l}\text { Low risk } \\
\text { Moderate risk } \\
\text { High risk } \\
\text { Very high risk }\end{array}$ \\
\hline
\end{tabular}




\section{A short literature analysis by using Web of Science database}

A detailed overview of the scientific literature shows, that there are not many publications on the ecological risk assessment of heavy metals in sewage sludge subjected to various processes used in the WWTPs (biological, chemical, mechanical). In order to give an approximate number of these papers, a short analysis was conducted. In our research we used the Web of Science Core Collection (WoS) database resources. WoS includes articles published from the beginning of the $20^{\text {th }}$ century to the present. Scientific papers were searched through the function "topic", which allows declaring selected search terms (words or phrases). Two search terms were declared, namely "ecological/environmental risk assessment of heavy metals in sewage sludge" (1) and "ecological risk assessment of sewage sludge" (2). First one allows us to distinguish 112 publications, but after a detailed analysis of the obtained results (conducted manually), it turned out that only 29 of them were closely related to the analyzed topic. The number of citations to those papers amounted 350, while the number of highest citations was recorded in the year 2020 (100 citations). The second search term allowed to revealed 209 publications, of which only 30 corresponded to the discussed issue. The total number of citations to those papers amounted 516, whereas the number of highest citations was recorded in 2020 (137 citations). Considering both search terms, most of the analyzed publications were published during the period between 2015 and 2017. The above mentioned analysis was carried out on November 16th, 2020. However, to conduct detailed analysis of the above data, more professional tools are needed, for example the CiteSpace software. This program gives a possibility to identify the past trends and future directions in assessment of the ecological risk of heavy metals in different types of sewage sludge. Unfortunately, most of these papers concern only the dewatered sewage sludge. For example Liu et al. (2015) found, that dewatered sludge characterized with a high values of RI and ER, especially for $\mathrm{Cu}$ and $\mathrm{Cd}$. Similar observations were also made by other scientists who indicated, that $\mathrm{Cd}$ present in dewatered sludge posed a high ecological risk (ER>160) Duan et al. (2017). It is worth to know, that processes of sludge treatment, such as stabilization, thickening, dehydration or hygienisation, may also contribute to the increase of heavy metals concentrations in sewage sludge. This means that every change that improves the characteristic of sewage sludge may also constitute a factor, which significantly affects the total metals concentration, and even the way of their binding in sludge. Thus, it is important to analyze the total concentrations of heavy metals, as well as their chemical forms, during various stages of sludge processing. So far, there are not many publications in this research area (Wang et al. 2006; Tytła 2019; Tytła 2020). Therefore, to the National Science Center (Poland) was submitted grant (project) under the title "The way of metals binding in sewage sludge and the ecological risk" (2019/35/D/ST10/02575), which was positively considered and is ongoing.

\section{Conclusions}

The use of sewage sludge from municipal WWTPs as a fertilizer, is the most appropriate method of its disposal, both in economically and environmentally aspect. Unfortunately, the presence of heavy metals in sludge limits its application to agricultural land. Admittedly, there are chemical, physical and biological techniques, which allow for heavy metals removal from sewage sludge, but it is still difficult to determine which method is the best. Taking into account the incomplete efficiency of these techniques and the fact, that heavy metals total concentrations do not provide full information about the possibility of their migration from sewage sludge to soil, surface and ground water, it is necessary to determine their chemical forms, which are not standardized by any legal act. One of the methods, that allow to assess the impact of heavy metals on individual component of the natural environment, is the analysis of the potential ecological risk. Such the analysis, carried out with the use of appropriate indices includes both 
the total content of heavy metals in sewage sludge, as well as their chemical forms of occurrence. Thus, it seems that analysis of the ecological risk is one of the best tools, which provide knowledge on how heavy metals present in sewage sludge affect the quality of natural environment.

\section{Funding}

This work was prepared in connection with the implementation of the grant entitled „The way of metals binding in sewage sludge and the ecological risk" (grant number 2019/35/D/ST10/02575) financed by National Science Centre, Poland.

\section{References}

Camargo FP, Tonello PS, dos Sanots ACA, Duarte ICS (2016) Removal of Toxic Metals from Sewage Sludge Through Chemical, Physical, and Biological Treatments - a Review. Water Air Soil Pollution 227:433. https://doi.org/10.1007/s11270-016-3141-3

Chen S (2019) Occurrence characteristics and ecological risk assessment of heavy metals in sewage sludge. OP Conf. Series: Earth and Environmental Science 295: 052041. http://doi:10.1088/17551315/295/5/052041

Council Directive of 12th June 1986 on the Protection of the Environment, and in Particular of the Soil, When Sewage Sludge Is Used in Agriculture (86/278/EEC). Available online: https://eurlex.europa.eu/legal-content/PL/TXT/PDF/?uri=CELEX:31986L0278\&from=EN.

Duan B, Zhang W, Zheng H, Wu C, Zhang Q, Bu Y (2017) Comparison of Health Risk Assessments of Heavy Metals and As in Sewage Sludge from Wastewater Treatment Plants (WWTPs) for Adults and Children in the Urban District of Taiyuan, China. International Journal of Environmental Research and Public Health 14:1194. https://doi.org/10.3390/ijerph14101194

Gusiatin ZM, Kulikowska D, Klik BK, Hajdukiewicz K (2018) Ecological Risk Assessment of Sewage Sludge From Municipal Wastewater Treatment Plants: A Case Study. Journal of Environmental Science and Health, Part A 53: 1167-1176. https://doi.org/10.1080/10934529.2018.1530333

Hakanson L (1980) Ecological Risk Index For Aquatic Pollution Control, a Sedimentological Approach. Water Research 14: 975-1001. https://doi.org/10.1016/0043-1354(80)90143-8

Ikem A, Egiebor N.O, Nyavor K (2003) Trace elements in water fish and sediment from Tuskegee Lake, Southeastern USA. Water, Air, and Soil Pollution 149:51-75. https://doi.org/10.1023/A:1025694315763

Kabata-Pendias A (2011) Trace Elements in Soils and Plants, 4th ed.; Taylor \& Francis: London, UK, $41-42$.

Liu J, Zhou Z, Sun S, Ning X, Zhao S, Xie W, Wang Y, Zheng L, Huang R., Li B (2015) Concentrations of heavy metals in six municipal sludges from Guangzhou and their potential ecological risk assessment for agricultural land use. Polish Journal of Environmental Studies 24:165-174. https://doi.org/10.15244/pjoes/28348

Macdonald DD, Ingersoll CG, Berger TA (2000) Development and evaluation of consensus-based sediment quality guidelines for freshwater ecosystems. Archives of Environmental Contamination and Toxicology 39: 20-31. https://doi.org/10.1007/s002440010075

Müller G (1969) Index of Geoaccumulation in Sediments of the Rhine River. Geo Journal 2: 108-118.

Perin G, Craboledda L, Lucchese M et al. (1985) Heavy Metal Speciation in the Sediments of Northern Adriatic Sea - A New Approach for Environmental Toxicity Determination. In: Lakkas TD, editor. Heavy Metal in the Environment 2. CEP Consultants; Edinburgh, Scotland 454-456.

Sakan SM, Djordjevic DS, Manojlovic DD, Polic PS (2009) Assessment of heavy metal pollutants accumulation in the Tisza river sediments. Jorunal of Environmetal Management 90:3382-3390. https://doi.org/10.1016/j.jenvman.2009.05.013

Spanos T, Ene A, Styliani Patronidou C, Xatzixristou C (2016) Temporal variability of sewage sludge heavy metal content from Greek wastewater treatment plants. Ecological Chemistry and Engineering 23: 271-283. https://doi.org/10.1515/eces-2016-0019 
Tiruneh AT, Fadiran AO, Mtshali JS (2014) Evaluation of the risk of heavy metals in sewage sludge intended for agricultural application in Swaziland. International Journal of Environmental Science and Technology 5: 197-216. http://doi: 10.6088/ijes.2014050100017

Tytła M (2019) Assessment of Heavy Metal Pollution and Potential Ecological Risk in Sewage Sludge from Municipal Wastewater Treatment Plant Located in the Most Industrialized Region in Poland Case Study. International Journal of Environmental Research and Public Health 16:2430. https://doi.org/10.3390/ijerph16132430

Tytła (2020) Identification of the Chemical Forms of Heavy Metals in Municipal Sewage Sludge as a Critical Element of Ecological Risk Assessment in Terms of Its Agricultural or Natural Use. International Journal of Environmental Research and Public Health 17:4640. https://doi.org/10.3390/ijerph17134640

Ure AM, Quevauviller P, Mantau H, Griepink B (1993) Speciation of heavy metals in soils and sediments. An account of the improvement and harmonization of extraction techniques undertaken under the auspices of the BRC of the Commission of the European Communities. International Journal of Environmental Analytical Chemistry 51:135-151. https://doi.org/10.1080/03067319308027619

Wang C, Li XC, Ma HT, Qian J, Zhai JB (2006) Distribution of extractable fractions of heavy metals in sludge during the wastewater treatment process. Journal of Hazardous Materials 137:1277-1283. https://doi.org/10.1016/j.jhazmat.2006.04.026

Zhao S, Feng C, Yang Y, Niu J, Shen Z (2012) Risk assessment of sedimentary metals in the Yangtze Estuary: New evidence of the relationships between two typical index methods. Journal of Hazardous Materials 241-242:164-172. https://doi.org/10.1016/j.jhazmat.2012.09.023 